\title{
A Beira Town in Protest: Memory, Populism and Democracy
}

\author{
JOSÉ MANUEL DE OLIVEIRA MENDES
}

'The universal is the place without walls' (Miguel Torga)

In this essay it is my intention to see how, in practice, a struggle is produced and maintained, what arguments, resources and relationships are mobilized, and what adversaries and allies are named. In a more descriptive logic, it is my goal to understand the dynamics, the contradictions, the paroxysms and the continuities of protest, that is, to understand the practice and the mundanity of protest actions.

Taking the common categories of indignation as object, I inquire about the conditions and constraints that lead to the distancing that is necessary for criticism (Boltanski and Chiapello 1999; Heinich 1999). For this I try to answer the following questions: When do indignation and criticism turn into collective action? How democratic and participatory is that process of mobilization? What allies and adversaries are produced? What material, relational, and discursive resources are used? What is the role of the leaders? Can these be bypassed?

For this case study, I chose the Movement for the Restoration of the Municipality of Canas de Senhorim (MRCCS). ${ }^{1}$ From the outset it has been a working class movement with some support from the middle classes. Although the town's economic and cultural elites were not hostile to the movement, due to their social and political networks outside the locality, they never directly participated in the movement's activities. The Movement's main aim has been to restore Canas de Senhorim as a municipality, reinstating the lost status in the nineteenth century and reaffirming its autonomy from the mother municipality of Nelas. This expresses a strong and deep radical localism that is crucial in the construction of personal and social identities in the town.

Since 1998, this Movement has acquired great visibility in Portuguese national public opinion, due particularly to the spectacular nature of the actions undertaken. This greater visibility derives from a change in the Movement's leadership, and the consequent expansion of its network of contacts. The Movement now takes as interlocutors the political 
organs at the national level. Thus, the demand for political recognition has entailed, in this case, the attempt to project and give visibility to the local space at the national level.

In a country with a long tradition of political and administrative centralization, it was after the Carnations Revolution of 1974 and after more than 40 years of a totalitarian regime, that local government and municipalities became symbols of the democratic process. As Ruivo (1999, 2000) has shown, it was only after this date that municipalities really obtained some administrative autonomy and could begin a process of local development. Local authorities, being elected, became the legitimate representatives of local populations and a new and important layer of political power in Portugal. Being a municipality made possible the access to financial resources and enabled the investment in infrastructures and in social services. It also allowed the municipalities to implement policies to attract investment. Furthermore, local government implied an administrative structure that meant opportunities to hire qualified personnel. The status as municipality became practically the only way for local development, especially in localities situated in the periphery of the country. However, the decentralization process was ambiguous and complex, and was established with the existing municipalities in 1974. There was much reluctance from central political power to create or redefine the administrative boundaries of the country, mainly for fear of igniting localism and old rivalries between local territories. ${ }^{2}$

This essay has two sections. In the first section there is a long and detailed description of the Movement, its beginning and marking events, its formal organization and the role of its leaders, its repertoire of actions, the important participation of women, the presence of violence and emotion, and the personal and collective identity processes of the Movement's participants. In the second section I reflect on the emancipatory potential of this concrete struggle.

\section{THE CONTEXT AND THE REASONS FOR A STRUGGLE}

Canas de Senhorim is located in the district of Viseu (interior centre region of Portugal), on a plateau between the River Mondego and the River Dão (Mouraz 1996). It is a town of around 4,000 inhabitants, mainly constituted by popular classes. Having received its charter in 1196 - confirmed by a second charter in 1514 (D. Manuel I) - it was governed as a municipality until 1852. At this time the former municipalities of Aguieira, Canas de Senhorim, Folhadal and Senhorim merged, thereby creating the municipality of Nelas (Various, 1975). The new administrative organization of 1867 allowed Canas to 
regain its status of municipality. With the January revolution of 1868 Canas de Senhorim once again became a parish of the municipality of Nelas.

It is only in 1975, a year after the Carnations Revolution, that the claims for the restoration of the municipality in Canas de Senhorim began. ${ }^{3}$ The town's population wanted administrative autonomy and the recognition of its economical and demographic weight in the existing municipality and in the region. Mainly supported by the local factory workers and miners, its leaders were local trade union leaders and primary teachers that used the trade union and leftist political parties organizational structures as ways to mobilize the population. The left-wing middle classes supported the struggle for administrative autonomy, mainly in the years following the Revolution.

The great strength of the movement was based on a memory and symbolic work that invoked the more than 650 years history of the town as a municipality, along with the symbolic and power rivalry with the town of Nelas, now the municipality's capital. This rivalry was also a factor that united different classes and social groups in the parish under the idea of a local and autonomous administration. This strong localism was, and still is, the motive force behind the will for autonomy in the town.

In 1975, after some popular meetings, a list of demands and a petition were drawn up and sent to the Home Secretary. In this claims book one can read that, 'despite its ample participation in the national economy and exchequer, [Canas] has always been a victim of the most severe oppression and exploitation' (Various 1975). The action of the Nelas Municipal Council was accused of overtly withdrawing infrastructures from the parish of Canas de Senhorim, and the signers of the petition appealed for the legal establishment of a decentralized local administration. They set a term of 90 days for receiving answers to their demands, and at the end of this term the popular assembly of Canas would delegate powers to the parish council to collect and apply taxes locally. Furthermore, according to the manifesto, the head offices of the large companies operating in the region should be transferred to Canas, as 'Nelas and Lisbon cannot continue to colonize Canas'.

The claims book emphasized the legitimacy of the local population to self-government due to the ostracizing policies from the municipality of Nelas and demanded the localization of economic power in the town.

The entities mentioned in this document as legitimate interlocutors for the application of the proposed measures were freely elected representatives of the people of Canas, delegates of the government or 
of the MFA (Armed Forces Movement), any negotiation with the municipal authorities being considered impossible. The action's leaders sought to project the issue of Canas's municipal autonomy to a level of national relevance, trying to mobilize the authorities recently constituted in the ambit of the ongoing revolutionary process in the country. They did this stressing the large working-class base of the population of Canas and the socio-economic power of this town in the context of the municipality, the district and the country.

Basically, the arguments are the same today. In a document included in the 'Process Relating to the Restoration of the Municipality of Canas de Senhorim', drawn up by the Movement for the Restoration of the Municipality of Canas de Senhorim (1999), they plead: 'Let Canas de Senhorim be free and dignified once and for all, definitively purging it of the old provocations in the form of the so-called internal neo-colonialism [emphasis in the original]'. In this document, the Movement also proposes, as a way of getting around the demographic criteria imposed by the Law on the Creation of Municipalities, two processes for creating municipalities: by law (quantitative, urban or administrative municipalities) and by the will of the people (qualitative, rural or historico-municipalist). It is the arguments submitted to justify this second method that I want to stress. They are justified by the idea of interiority and the need for balanced and sustained socio-economic development. Thus, in order for a municipality to be created, according to the Movement, the following aspects need to exist: conditions and structures equal or similar to those of the mother municipality; the will of the people, shown in several public acts (the argument of local representation); and municipalist traditions (a historical argument).

However, there is an important difference between the earlier demands and protests and the current ones. Before, constant references were made to the fact that Canas was one of the most populous and industrialized towns in the district of Viseu, contributing half of its gross domestic product. At present, after the closing of the Portuguese Electric Oven Company in 1987, and the consequent loss of economic influence in the municipality and the district, the Movement's documents now stress the spirit of progress and the high level of skills of the human resources in the town of Canas. It is felt that one of the main obstacles to the development of Canas is the need that the skilled workers feel to seek work outside the parish.

After the factory closing, and due to their professional skills, almost all workers found employment in factories in nearby localities. ${ }^{4}$ Other became small entrepreneurs or administrative clerks. The consequent economic instability forced also women to look for jobs. 
This was a great change in the family and social dynamics of the town. It really increased the living standards for most families and, most importantly, brought women to the public sphere creating new sociabilities and consumption patterns. On the other hand, it put women with the burden of the double shift, as the traditional sexual labour division in the households remained almost unchanged.

With the normalization of the national political life and the end of the revolutionary period in 1976 in Portugal, the population of Canas participated in the first free national, municipal and local elections. The Movement's activities were restricted to sparse local meetings and some reunions with leftist political parties. The elected Mayor of Nelas for the first two mandates $(1976-79 ; 1979-82)$ was José Correia from the PPD (Popular Democratic Party $\left({ }^{5}\right.$ He established a policy of noninvestment in Canas and this orientation, reinforced with his being from a party from the right, created a negative impact in the working class population of Canas.

The presentation in March 1982, by the Social Democratic Centre (CDS) of a bill in Parliament for the creation of the municipality of Canas de Senhorim, reactivated the local demands for autonomy. This legal initiative, politically institutionalizing for the first time the fight for the municipality, united the different social classes and groups of Canas. It was a proposal by a political party that participated in the national government, in coalition with the Popular Democratic Party (PPD). ${ }^{6}$ Although the Movement leaders were from the left wing parties, namely Popular Democratic Union, a maoist party, the Socialist Party (PS) and the Portuguese Communist Party (PCP), they saw here the opportunity to give a national dimension to the struggle and a way of responding to the grievances by the Mayor of Nelas.

In May 1982, the newly named Committee for the Creation of the Municipality gave a press conference where it submitted the following demands: a specific postal code should be created, express trains should stop in Canas, there should be a health centre, and the bill submitted by the CDS should be discussed in Parliament (Jornal de Notícias, ${ }^{7} 1$ May 1982). These demands were strategic to mobilize the feeling of localism in the population and were presented as signifiers of the ecomomic and symbolic power of the town. At the time, the newspaper JN took up a position favourable to the demands of the Canas Committee, publishing several pieces condemning the deplorable state of the infrastructures in the town and putting the struggle for the municipality into a historical context (JN, 20 May and 1 July 1982).

On 30 July 1982 the CDS's bill was not voted on in Parliament for lack of a quorum. On 2 August 1982, the population of Canas gathered outside 
the Post Office to prevent the mail from leaving and to demand a postal code. This action was a response to the Parliament's refusal to discuss the bill about Canas de Senhorim. It was also a demand for a visible and concrete measure that could signify the real importance of the town and its autonomy from Nelas. This was done also in a national context of social and political instability, the national government having faced many labour strikes and a general strike on February 1982. For many of the Movement's leaders, the national government was weakened and this was the time to push forward by a spectacular action that presented the local struggle to the national public opinion.

On 2 August 1982, when the people realized that the mail had been removed earlier, the building was taken over. Spontaneously, they then decided to block the railway line. As the JN writer stresses, this measure had a great impact, as it was an international line and was used by many emigrants at this time of the year. More than 100 metres of rails were taken up. As word was passed that the Republican National Guard (GNR) was outside town ready to take action against the population, the fire siren and the church bells began calling for the population. Hundreds of factory workers and miners with their relatives and wives gathered on the railway, turning this event into an instance of the local resistance against centralism and its representatives, mainly the security forces. Many years of ostracism by the local and national authorities converged on this event, and beyond political or social differences, the population had an opportunity to unite and bond around a feeling of community, in an almost mythic fusion of minds and bodies, as many of the interviewees told me.

Meanwhile, the GNR had taken advantage of the absence of the people who had gathered at the railway line to occupy the Post Office building. The fire siren sounded again and the people returned to the Post Office. The GNR used force. The population retook the building, and mounted a picket line. When the people returned to the railway line they found the GNR's riot troops there. An agreement was reached with the GNR commandant. The police did not intervene, and the people remained on the railway line.

The next day, after a meeting with the authorities at the Viseu Civil Government, the movement, in a popular assembly, decided to raise the blockade. It was also decided that from then on 2 August would be observed as the symbol of the future municipality of Canas, as against the Nelas municipal holiday, which is celebrated on 24 June (JN, 4 August 1982).

On 26 September 1982 a plaque commemorating the 2 August would be unveiled. Since then, there has only been one year when that day was not commemorated. The commemoration is of a popular and solidary 
FSES FSES090204-29/6/2004-KREETHI-110686

104

REINVENTING DEMOCRACY

nature. Sardines, wine and corn bread are distributed freely to all who are present. As one of the interviewees said, after that date:

the Movement's only action was the 2nd of August. ... It didn't happen only once, one year ... The 2nd of August became the people's holiday. The people's holiday. We had lots of people here, sometimes people who came and said, 'hey, mate', emigrants and foreigners who appeared, 'Hey, mate, this is different, in a country like this, to have a party where people eat, drink and don't pay. Where else can you see this?' ... We clubbed together, and people went round collecting money. (Carlos Henrique, ${ }^{8} 8$ August 2000).

But more importantly, this date recorded the population's capacity for mobilization around the ideal of the restoration of the municipality in the collective memory, projecting the struggle to a national level (Ruas 1994).

Q1 It was the first violent action in the municipality's reivindicative process, showing the local will to resist the impositions of the municipal, district and national authorities. The annual commemoration of this date is part of the practice and the memory of popular resistance and solidarity, and celebrates the communion of all the people in a decommodified event with no social distinctions or privileges. It is the only moment, together with the town's famous Carnival, that class differences and social hierarchies are bracketed and the community commemorates together. By gaining its own postal code in 1983, this was a small reward for those who believed in the possibility of gaining administrative autonomy, and a sign that sometimes violent action can bring some results. To date, this was the only visible national policy success in the long history of the Movement.

In the local elections of December 1982 the candidate of the PS, José Albuquerque Vaz, was elected as Mayor of Nelas. Being a natural of Canas he began a strong policy of investment in infrastructures in the town. The Movement maintained its informal meetings, participated in only by the leaders. The only public presence of the Movement from 1982 onwards was the yearly political rally of 2 August.

Another politically important date, and a local policy success for the Movement was later when, in 1986, it stood for the parish council elections with its own list of candidates, the only opposition being the PS. The Movement won by a large margin. This date coincided with the beginning of the crisis at the Portuguese Electric Oven Company. The parish council took up many positions condemning the critical situation at the company, and the difficult labour situation came to overshadow the demands for the administrative autonomy of Canas. Also the Nelas Mayor elected in 1985, José M. Lopes de Almeida from 
Social Democratic Party (PSD), maintained a policy of strong support for the town of Canas. With the closing of the factory and the dislocation of workplaces, the Movement entered a long period of stagnation.

In the remaining parts of this essay, I will concentrate on the most recent years of the struggle for the restoration of the municipality of Canas, which has been renewed and intensified since 1997.

\section{Formal Organization and Leaders}

At the end of 1997, some of the leaders of the Movement who had remained since 1987 contacted Luís Pinheiro, a local high school teacher, to reactivate the movement. He had been the president of the parish assembly, for which he was elected by the PSD from 1993 to 1997 . He was also the defeated candidate for the PSD to Mayor of Nelas in the local elections of 1997.

This reactivation of the Movement can be explained by two factors. José Correia Lopes, the Mayor of Nelas from 1976 to 1982, had been re-elected in 1989, now by the PS. ${ }^{9}$ He maintained his personal orientation of not investing in Canas, and the fact that he was now a candidate for the PS caused many socialists from Canas to withdraw their support from the local policies of their political party and to appeal to a more vigorous political presence by the Movement. On the other hand, the majority of the town's workers and their families now had more stable economic situations, and they felt that only administrative autonomy could stop the declining position of their town when compared with the mother municipality or other neighbouring towns.

Luis Pinheiro sought to institute a collegiate leadership structure for the Movement which would bring together representatives of all the political parties. This was a strategy to unite all social groups around the struggle for the status of municipality. In an extended meeting he was elected leader. The Movement's leadership would maintain the presence of the former leaders, who symbolized the continuity of the struggle and its popular roots; but it included also representatives of the PS, the PSD, the Social Democratic Centre/Popular Party (CDS/PP) and other parties of the left. At present, the PS has just one permanent representative, and the other parties of the left have none. Despite the effort to keep the Movement above the parties, party political logic turned out to be the factor that caused most friction within the movement and its supporters.

Indeed, party political identification is a crucial identity marker, especially because of the personal, family and relational divisions it creates. At this stage of the struggle, the Movement's great enemy is the PS, especially some important figures, such as the Mayor of Nelas (José Lopes Correia), the leader in the Viseu district, the Speaker of 
FSES FSES090204-29/6/2004-KREETHI-110686

106

REINVENTING DEMOCRACY

Parliament, and the leader of the parliamentary benches. Those in Canas who are PS members and also feel close to the Movement are divided between local solidarities and pressures and the biographical, political and ideological allegiance to the party. The resolution or lessening of the ideological dilemmas in which they are entangled involve the personalization of their party's negative attitudes. In order to protect the party, which has always received strong electoral support in Canas, they attribute negative positions to personality traits, as well as to the personal interests of some municipal, district and national leaders.

The personal party orientation of some of the people I interviewed, in almost all cases decided after 25 April 1974, has a decisive and important influence on the identity levels activated and the broader levels of political and social involvement. These levels include the personal and unique, intermediate spatial and institutional identifications, as well as broader identifications, such as the country (Auge 1998). For reasons of identification with the party leader, ideological choice, influence of local dynamics, hatreds and passions, and especially the choice of party of personal and family adversaries, the chosen party indelibly marks opinions and political positions. ${ }^{10}$

Although the Movement's supporters in their majority put the local struggle above their political allegiances, it is predictable that when Canas obtains its status as a municipality all the force of party identifications will come to the front and new alliances and confrontations will be established.

In the Movement today, we are faced with the crossing of different memories, with different temporal depths. For the new leader, the important references belong to the most recent years (1998-2000). For those who have been in the Movement since 1975, what is important, with its highs and lows, is the permanence of the struggle and the capacity for resistance. Some interviewees made a clear distinction between the current Movement and the former one in terms of goals and methods. The strategic capacity for mobilization therefore depends on an appeal directed towards different memories and common histories and narratives. As Jeffrey Rubin says, 'these ambiguities and contradictions suggest that it is the coexistence of multiple forms of difference that animates a radical social movement' (1998: 160).

The strategic appeal by the Movement's leader to the localism ideology and the rivalry with Nelas town, along with the mobilization of the strong local identities of those who were born in Canas de Senhorim or have lived there for many years, puts the Movement above the political parties. This is also facilitated by the fact that the Mayor of Nelas has been in power for more than ten consecutive years, not investing or attracting factories or other investments to the town of Canas. These facts 
allow a clear identification of the local adversary and create an ideological consensus around the main goal of becoming a municipality. This is an ideological binding force that overcomes particularisms and party identifications. The political fight, as the new Movement's leader says, is against the local and the national governments and demands allegiance to this cause and no other. This demands a constant identity work of defining the in-group against all the adversaries from the outside, being they in the municipality, the region or in the national level. The Movement has a core group of five people around the leader, constituted mainly of small entrepreneurs, all ancient factory workers and some in the Movement since 1975. The Movement has weekly meetings with the population. The people who go to the meetings regularly ${ }^{11}$ are, on the whole, thought of as political mediators and people of privileged opinion in the locality. They have wide networks of contacts and knowledge, and are given a respected position in the hierarchy of local credibility.

Of those who regularly attend the meetings, the majority are factory workers, some are teachers, administrative clerks and peasants. Of the women who attend, the majority are housewives, along with some factory workers and administrative clerks. The most striking feature is the complete absence in the meetings of the representative of the economic or cultural elites, this being a clear indication of explicit reinforcement of the popular composition and ideology of the Movement after 1997.

At the organizational and logistical level, the support of the Canas parish council is important to the Movement. ${ }^{12}$ The Movement's weekly meetings with the population are held in its offices. These meetings, instituted in 1998, are an exercise in confrontation and an explanation of arguments. As one person remarked in conversation,

The meetings are educational. At the beginning there was great confusion. Everything under the sun was talked about. People came with personal hatreds and grudges. There were intentions to give up the meetings. People learned how to behave at these meetings. They learned to submit pertinent topics, not to get excited and to explain their points of view.

This learning of a democratic debate materializes and ritualizes the closeness of the Movement's leadership to the people. Although the meetings are guided by topics submitted by Luís Pinheiro, given his privileged relationship with the national political organs and the media, many people take an active role in the meetings. These meetings are seen by the leaders as an opportunity to control the more radical elements, allowing their discontent to be voiced and arguments to be rationalized. 
FSES FSES090204-29/6/2004-KREETHI-110686

108

REINVENTING DEMOCRACY

But they also force the leaders to face resistance, to explain attitudes, affirmations and actions. Although the decisions to be taken regarding the Movement's concrete actions are made by a restricted group of leaders, the weekly justification of these decisions has become an imperative.

It should also be emphasized that the participants in the meetings constantly activate a policy of vigilance in relation to everything that is said or written in the local, regional and national media about Canas. The participants in the meetings conduct a practice of careful, deconstructive reading of the news stories and reports, imputing intentions, defining allies or adversaries, categorizing favourable and unfavourable positions, and consequently placing the reports analyzed into a continuum of closeness and localism (valorization) or distance (devalorization).

To maintain a close relationship with the general population, the new leader also initiated monthly rallies, where the Movement could expose its initiatives and lines of action, and maintain a constant arousal against its political adversaries. These rallies were normally attended by 400-550 people, the majority of them from the popular classes with some from the middle classes.

The greatest tension that runs through the Movement, visible at many of the meetings I participated in, comes from the precarious balance between the radicals and the moderates. The moderates, represented by the leader, have a more political, medium and long-term vision. They place the struggle in a logic of party political strategy, favouring negotiation and institutional viability, waiting, if necessary, for a national alignment of political forces which will be more favourable to the process of establishing the new municipality. ${ }^{13}$ The radicals, less closely linked to party logic and closer to a fundamentalist working class ethic, base their arguments on a moral logic, of personal and collective offence and indignation. The central argument on which this moral position is founded was well summarized by Manuel Alves when he said that:

It's like this. There are people who like to live under the control of others. There are others who don't. Canas de Senhorim doesn't. It's a place which thinks it should never be dominated by others. So they think it should be set free, like any other place. Just as Portugal thought, and as other nations thought, so as never to be dominated by others. (24 August 2000)

What prevents the polarization of positions and allows some tolerance is the ideology of brotherhood and the crucial role of the family in the structuring of social relationships. The great closeness between the men comes from a common past as employees of the Companhia de Fornos 
Eléctricos or of the Minas da Urgeiriça. Many participated together in protest actions, and the fact that they had worked together gave them a sense of community and a capital of trust that are very hard to break. This idea of brotherhood and the common memory of work prevent the radicalization of positions against those who are less favourable to or against the Movement. Although some voices are heard threatening more extreme actions against those who are against the Movement, these have never been carried out. In many cases, the example of the radicalism of Vizela is invoked ${ }^{14}$ with the idea of regretting that similar actions were not applied locally. Basically, we have a counterpoint between a political pragmatism and a moral vision based on the principles of dignity, honour and familism. ${ }^{15}$

The weekly meetings, a populist and demanding democratic exercise, force the leaders to present and justify their opinions and decisions before the people they represent. ${ }^{16}$ Leadership is never a given, and demands the constant exercise of rhetoric, argument and justification. It is always seen and read as provisional, as demanding a constant labour of affirmation and confirmation. Knowing how to listen to and accept criticisms in the meetings is an indication of the leadership's democratic nature. Knowing how to speak and explain points of view shows the leader's ability to represent the Movement to the outside (media, politicians), where a good command of language, a good physical appearance and a persuasive argumentation are needed.

The provisional nature of leadership, always dependent on concrete results and achievement of the goal of administrative autonomy, as well as on the balance of forces between the more radical elements and those who propose a political, negotiated strategy, was clearly evident in the interview Luís Pinheiro gave me.

I tried, and I only managed to get people to be on my side and to rise above the logic of the parties and each one's party. Each one's party has always been respected. This has been the great exercise of my mandate, let's call it that, in the Movement. It was to open the game to the people. To open everything to the people. We have meetings open to everybody. No politician does that. And if I wanted to I wouldn't. I'd be respected just the same. People would follow me just the same. ... And it's difficult to face the people every week. Because they don't all think the same way. Everyone can give their opinion. Some think we should take action, others think we shouldn't do that. This is very difficult to manage, and few people want to be exposed to situations of this kind. ... I've learned a lot from people and people teach me a lot.... Now I understand that at 
a political level, in any chamber, this can't be opened up in this way, or chaos would set in. But it's good that people realize that the people are increasingly less stupid. The people increasingly know more and see more. And now nobody is smarter than anybody else. We see these politicians increasingly going under from one moment to the next because really they think they're still working for idiots. They can't understand that nowadays the people around them study. Nowadays people have a different level of culture, they have the Internet, they have television, read newspapers, listen to the radio and are informed. They are beginning to understand the system. There has to be a different kind of respect for people.... And I think that this is an exercise that I'm going to undertake and continue to the end. And if I go under with this, I'll go under with pleasure and I'll go under with honour. Because I'll go to any length to tell people the truth. (19 September 2000)

Here the interviewee again emphasized his intention to maintain the Movement as a means of writing regardless of the party political options of each individual. Stressing that he considers himself a democrat, he mentions that the weekly meetings were his idea and he has always had the option not to hold them. Here, he emphasizes his role as leader, as capable of imposing a direction and a practice. But, having instituted the ritual of the meetings, doing away with them would be dangerous to his leadership. He himself recognizes that people are much better informed, and the meetings also serve to channel passions, emotions, and feelings, and to clarify criticisms and radical positions and make them public. Without the meetings, it would be almost impossible to control the more radical elements. Without a framework of some kind, their actions would become unpredictable and could put the Movement's entire strategy of institutional negotiation at risk. The voicing of radical ideas makes them visible and the arguments put forward can be contested, normalized and soothed. ${ }^{17}$

What separates the Movement's leadership from the other supporters has to do with the means for achieving the goal of raising Canas to a municipality. While the former adopt an overtly political pose, reflecting on and strategically weighing every action, seeking to mobilize the political organs at local, regional and national level, the latter, with memories of long hard struggles, demand immediate results, proposing drastic actions, especially directed against the local government that dominates them. This gap between strategies and territorial levels of relevance of action creates ambiguities, contradictions and compromizes which have to be constantly negotiated, assessed and controlled. 
Following Santos's suggestion (1995: 482), the relationship of the Movement's leadership with its supporters appears as a negotiated form of the transformation of power into shared authority. The dilemmas of choice between institutionalized/non-institutionalized action, between legal/non-legal actions and between violent/non-violent actions, which all social movements face (McAdam and Tarrow 2000), are felt more by the leadership of movements than by their supporters, and the latter often end up going too far or forcing the leaders into unplanned, unprogrammed, more radical actions.

Besides his organizational and rhetorical skills, the current leader's great trump card is that he mobilized and interested a party with great a national profile like PSD in the cause of raising Canas to the status of municipality. ${ }^{18}$ The bill submitted in 1982 had been an initiative of CDS, and in the years that followed (1983, 1986 and 1988) the initiative came from the PCP, ${ }^{19}$ two parties with unimportant representation in Parliament. The support of the PSD after 1998 reignited the hope of those who fought for the municipality and broadened the Movement's support base, reinforcing the new leader's legitimacy and his calls to unity above party identifications.

\section{The Repertoire of Actions}

From 1998 the Movement adopted a set of action strategies which projected it to the national level, and appeared as a break with past actions. Modernization of the repertoire of actions included extreme attention to the effect of the struggle on the media and the adoption of spectacular forms of action. The Movement's leader acknowledges that getting media attention was the most difficult part of the struggle, because there is always the risk that statements or actions will be interpreted negatively, harming the Movement's goals. The targets of the actions, with occasional exceptions, had now become political organs and institutions at national level, especially Parliament. There was an explicit will to be innovative and radical at the actions chosen, with the sole aim of calling the attention of national media and public opinion. This was done by a clear symbolization and aestheticization of all actions, carefully selecting the rituals, the props and the chants to be used.

The most important moment in the intensification of the struggle occurred on 19 November 1998, when discussion on raising more than 20 places to the status of municipality was scheduled in the Parliament. The conference of leaders in the Parliament ended up agreeing to discussion and voting on only two new municipalities, Trofa and Odivelas (JN, 19 November 1998). For the people I interviewed, this was 
the most negative moment of the whole process of the struggle since 1975. Party alignment at this time was favourable to Canas. The news of the non-tabling of Canas was received by those who were in the Parliament with great emotion. As Carlos Henrique told me:

When we were in Parliament, some time ago, when it arose, when it was supposed to come up for discussion, and when only Vizela [it was Trofa, not Vizela] and Odivelas came up and we did not come up, I was there in Parliament. And when they came to us saying 'Hey, Canas didn't come up!' Hey, some were crying, there were four of us, some were crying and I shouted.... We were crying, some on one side, some on the other. We were shouting, we were crying. We stormed the Parliament, we shouted, everyone was fleeing, watching, everything. It was... it was the most dramatic moment, for me it was. (8 August 2000)

From then on the attitude of those most directly linked to Canas's struggle was characterized by indignation against political power and its strategic games. It was an indignation against the asymmetry of power and the failure to respect political promises. As Carlos Henrique mentioned, 'This is shocking. They make fun of us, and later when we see that they're playing with us, there's nothing we can do. Have you seen? They think they are the bosses, above everyone, they are the greatest. They are the MPs, they're the greatest, and you put up with it and that's that'.

In January 1999 a petition was sent to the Speaker ${ }^{20}$ asking for the discussion of, and voting on, the bills about Canas. On 2 February there was a demonstration outside Parliament with 234 citizens, one for each MP. On 2 March, 12 Canas men began a hunger strike on the steps of the Parliament building. This was suspended the following day, after appeals from some PSD MPs, and this party's promise to schedule discussion of the Canas project. On 9 March people from Canas demonstrated outside Parliament with nooses around their necks. The scheduling of the discussion about the parties' bills concerning Canas was due on that date. The press attributed the fact that this did not happen to the direct intervention, for the first time since he had held the office, of the Speaker, Almeida Santos from the PS (Diário de Notícias, 24 March 1999).

These last actions had notable repercussions in the national media. The cartoons published in the Diário de Notícias and Público were significant. ${ }^{21}$ On 18 March, after the Movement held a rally in Canas, people blockaded the Beira Alta railway line. On $28 \mathrm{March}$, at the Almeida Garrett (a national writer from the nineteenth century) commemorations in Porto, attended by the President of the Republic, the people of Canas demonstrated for their municipality. According to 
the report by journalist Domingos de Andrade of the JN, Jorge Sampaio did not like this action, and appealed to national unity against administrative divisions (JN, 28 March 1999). More important was the symbolic act of refusing political citizenship by many demonstrators, who on this day burned their voting cards in an improvized ballot box. In this way they showed their distance from the national institutions and the political system, abdicating their right to vote.

These actions show an explicit strategy of continual pressure on the organs of sovereignty, seeking to raise the profile of the Movement and embarrass the national authorities. However, they also show great ability to mobilize the town population, which has managed to be present in significant numbers in different scenarios and situations.

On 19 April 1999, ten members of the Movement's leadership began a hunger strike on the steps of Parliament which lasted until 25 April. This extreme action taken by nine men, the leader and the core leadership, and an old woman, was strategically intended to project nationally, through the suffering bodies of this small group, the struggle of the town. The date chosen, coincided with the commemorations of the Carnations Revolution (25 April 1974), intended to show that there was a town that claimed freedom in the spirit and the tradition of the 1974 political revolution. The chosen action was an indicator of how radical and strong-willed they were fighting for their town's autonomy. It was an unexpected action that had great media impact.

The memory of this action is painful for those who participated in it. The Movement's leader was accompanied on the strike by his mother, a lady of advanced age, which made him more vulnerable and sensitive to the suffering of the other strikers. When I interviewed one of the participants in the hunger strike, his wife remembered those days of expectation and absence in silence, and her eyes were full of tears which she tried to hide.

But what most impressed the participants and the people of Canas was the indifference of the MPs and politicians to the strikers. Nobody came to talk to them or ask them about their complaints. This extended strike culminated on 25 April, with the beginning of the commemorations of the April Revolution. The ceremony took place in Parliament, in the presence of the Speaker of Guiné-Bissau and the President of Mozambique. The demonstrators from Canas called the Speaker and the President of the Republic fascists when they arrived for the ceremony (JN, April 1999).

An element of the stories told by the people of Canas, which was not reported by the newspapers, is the surprise they had at how little security there was at the Parliament, which allowed them to get very 
FSES FSES090204-29/6/2004-KREETHI-110686

114

REINVENTING DEMOCRACY

close to the Prime Minister and see the fear and surprise stamped on his face. It was a desacralization of power, and a momentary inversion of the hierarchy of power.

But the actions most aimed at the media were reserved for the official commemorations in the Parque das Nações. The demonstrators who came from Canas with banners decorated with black carnations as a sign of mourning were following what was happening at the Parliament by radio and communication with acquaintances and family members. According to later reports, spirits were exarcerbated and when they got to the Parque das Nações they were prepared for the worst. The principal figures of the state, especially the President and the Speaker, were met by the people of Canas with cries of 'fascist, fascist'. When the national anthem was played, the protests, shouts and chants continued. Some of the participants claim they did not even notice the anthem. Most of the people I interviewed consider this to be the most significant moment in Canas's struggle to become a municipality. Press coverage was enormous, and, some argue, they managed to show the foreign leaders and the diplomatic corps the situation of injustice and oppression that exists in some regions in Portugal.

These events were assessed very negatively by commentators in the national media. ${ }^{22}$ As an example, in his article in Visão magazine (29 April to 5 May 1999), with the title 'The 25th of April Deserved Better', Cáceres Monteiro, after writing that the commemorations of 25 April had been disappointing and routine, goes on to tackle the action of the people of Canas. To quote:

Also seen was the regrettable demonstration by the inhabitants of Canas de Senhorim, on the steps of São Bento (including insults to the President and the Speaker) and at the military parade - with hoots and whistles at the national anthem. After this act of extremely poor civic education, unless the population of Canas discredits the delegation of political hooligans, the place had better give up on its aims. Wretched parish! ${ }^{23}$

This commentary forms part of a journalistic logic, inherent in the very format of the opinion article, which Shanto Iyengar (quoted in Jasper, 1997: 79) calls episodic framing (stories told as single events) as against thematic framing (events set in a broader social context). No information is given by the writer about the reasons for the demonstration. In addition, the application of the label 'hooligans', normally associated with disorderly young football supporters, denigrates the demonstrators of Canas, lumping together women, people who had just finished a long hunger strike, children, young people, labourers with a long tradition of struggle and resistance, civil servants, employers, and so on. 
In Canas's long tradition of populist struggle, the demonstrators, against an intellectual and journalistic vision of 25 April, and in a logic of appropriation, normalization and institutionalization, sought to deconstruct in practice the reified categories of freedom, democracy and people. By intoning the slogans of the revolution, they sought to create a spectacle within a spectacle, undoing and denouncing the exhibitionist logic of the commemoration. They were recuperating, through invocation, the revolutionary and popular celebration of freedom. This can be read in the arguments put forward by Manuel Alves:

The press has not been correct in their not getting adequate information about the reasons behind these demonstrations, these struggles. It's not enough to show up and criticize. As they did, for example, on the 25th of April [1999], when they criticized what I feel should not have been criticized. Because, see, they failed even there, because the 25th of April is a time of struggle and freedom. That wasn't done by chance. Precisely to free the people. And we thought the 25th of April was the ideal time for us to plead for our freedom. And so we did. Now, to say there were excesses, which there were, but what struggle doesn't have excesses? ${ }^{24}$ (24 August 2000)

The Movement's leader, Luís Pinheiro, also considers this date to be the most important since he took over the leadership, although his vision is more strategic:

I think the most important moment we had, which may have been negative from the media's point of view, was the 25th of April. The 25th of April registered decisively in the politicians' heads that this was a problem that they had to treat differently. It may have been a complicated way, but it was decisive. ... It was a process we had to go through to get that media coverage, to gain a position in the head and spirit of the politicians. And we did it. In the end we succeeded perfectly. ... Today I enter Parliament and everybody knows me. (19 September 2000)

The Movement's actions would continue throughout the year, with great media visibility. They would be present in Tondela when the Prime Minister opened a landfill site. They would jeer at the Speaker when he was honoured by Dão gastronomic fraternity (Público, 24 May 1999). And, on 10 June, the day commemorating Portugal, Camões and the Portuguese communities, they would appear, gagged, in Aveiro (Público, 10 June 1999). They would also boycott the European elections (in June) and the parliamentary elections (in October), and the elections for a new parish council. 
FSES FSES090204-29/6/2004-KREETHI-110686

116

REINVENTING DEMOCRACY

To finish this point, it seems pertinent to mention that an article from Visão magazine (25 November to 1 December 1999) indicated that the President had reviewed his position on Canas de Senhorim. To quote, 'His advisers have mapped out the historical and sociological causes behind the desire for separation from the municipality of Nelas, and Jorge Sampaio promises to follow the case closely, helping to tackle the fundamental problems of that community'. The President became a potential ally, and today still has an adviser in regular contact with the Movement's leaders.

In the prosecution of the goal of raising Canas to municipal status, the Movement's actions, very intense and frequent in 1999, can be seen as attempts to redefine the state's positions and actions, setting a localism of resistance against a centralist and centralizing vision, a democratic law against a despotic law (Santos 1995: 482), based on the memory of a struggle and on populist and egalitarian ideals. In the structural space of citizenship the appeal is for a radical democracy, both in its vertical component (relationship between citizens and the state) and in its horizontal component (relationship between citizens and their associations) (Santos 1995: 486).

\section{Women's Participation}

The women of Canas have had a powerful and constant presence in the public actions carried out by the Movement. They sing the chants at demonstrations and rallies. They were present at the electoral boycotts I witnessed, keeping a permanent watch throughout the night. They also take part in the weekly meetings. Thus, the women have their own, visible standing in the public space. However, they have never had important positions in the Movement's leadership structure. The role and the presence of women is a given for the people, and they do not question the sexual division in the political work of representation.

Some interviewees have attributed their visibility in the public space of protest to a personality trait in the Beira's women, who have always been very determined and active in issues that affect them directly. Others look for socio-economic reasons, because since the closure of the large companies which were based there, it was the women who most felt the first years of recession and economic difficulties as they were forced to look for work, often shift work, outside Canas.

The Movement's leader himself recognizes that this is a topic he has had difficulty in tackling and explaining, though he has stressed that the women are often the most radical and most difficult to control in the public actions conducted by the Movement. In the Movement's weekly meetings, 
FSES FSES090204-29/6/2004-KREETHI-110686

the women intervene with comments and suggestions, but rarely assume leading roles. Delegating to men the work of representation and mediation with the outside is taken as natural, and I never witnessed an occasion when this situation was questioned or even discussed.

The arguments put forward by Clara Simões in the interview she gave me seem interesting:

JM: I've noticed that there are many women who go to the meetings and go to the demonstrations, but there are none in the leadership.

CS: Yes, really they haven't put any women in the leadership. I don't think there is a single one, right? Though there are plenty who work with them.

JM: But there have never been any in the leadership?

CS: No, I don't think so.

JM: Why do you think that is? Do you think it would be important to have...?

CS: Well, at that time, in my personal opinion, I think it was still in that phase when men were men, men knew how to talk to politicians, because they had a little, okay, machismo. Today, obviously, things are still the same and have continued, and they haven't yet remembered to put in a female warrior, I don't know! And us, as we know it's in good hands, we let it go, right? (uh uh) Really, they've been extraordinary, they've been, poor things, they've slept badly at night on the way to Lisbon and coming back. Poor things, really they've been marvellous. As for there being no women yet, let's hope that in the next, the next elections they elect one, right? I don't know (27 July 2000).

The interviewee, who until that concrete question had spoken of the Movement as a structure that united the local residents, especially in surmounting individual party logic and identifications, always using the pronoun we in a clear process of collective identification, on this topic used the pronoun they to refer to the Movement. In arguing that the movement previously applied a sexist policy (machismo) in the choice of leaders, because men were considered to be better prepared for talking with politicians, she tried to distance herself from this sexist logic and practice. At the current stage, where greater equality in the relationships between men and women may be supposed, Clara Simões described the women who support the Movement as 'female warriors', and 
FSES FSES090204-29/6/2004-KREETHI-110686

118

REINVENTING DEMOCRACY

attributed the continuation of these sexist practices to forgetfulness, showing the extent to which this topic is forbidden in the rhetoric surrounding the Movement's actions.

Hoping that this situation will change in the near future, Clara Simões immediately tried to modify her statements, emphasizing the effort, the dedication, the sacrifice, and the self-denial of the current leaders. In the quick description she gave of the leaders' duties, such as, for example, the journeys to Lisbon, the long nights of work and meetings, she applies the traditional logic of men having more time available, the result of a sexual division between domestic work and the work of public presentation and representation. The resolution of the ideological dilemma my question raised led Clara Simões to reiterate the qualities of the leadership, so that for her there was no need for women to intervene.

\section{Violence and Emotions}

In the concrete case of Canas, this community is characterized by a strong distrust of everything that is external to it. A constant watch is kept on outsiders, seeking to assess their intentions and their orientations regarding the cause they find themselves involved in.

Having taken part in some violent situations since 1982, people see violence as a last resort to raise the visibility of their demands. As Carlos Henrique told me, commenting on the situation of development in Canas compared with 20 years ago, 'It only makes you want to throw stones at these guys. And kill one of them. This (Canas' struggle( will only have a solution when we kill people and people die. This only will end when people die. It could be me'. Carlos Joaquim also put forward similar arguments:

We have to take the struggle forward, whatever the cost, we have to take a beating, this has to be resolved. We know the history of Portuguese politics. It's only when blood flows that problems are solved. Look at the IP5 (highway linking the city of Aveiro to the Spanish frontier(. A hundred-odd people died before they built the third lane.... There has to be blood for them to sit round the table and sort things out. When things have to be sorted out beforehand.... We have active men here. If this causes problems, they [the politicians] are responsible. (15 August 2000)

To describe the role of violence and emotions in the production and reinforcement of personal and collective identities and in the definition of possible words, I will relate two episodes I witnessed. The first had to do with setting a date for by-elections for the Canas parish council. 
By agreement of all the local representatives of the most important political parties, no list was submitted, and the intention to boycott the elections remained in force. But to everyone's surprise, a list from the National Solidarity Party (PSN) appeared. ${ }^{25}$ People's reactions in the weekly meetings were very negative. Their candidacy was considered an offence and a complete degradation of the integrity of political values, as an intrusion from the outside into local life and order, exarcebating the ideology of localism in the Movement's supporters.

The presentation of the PSN ticket was set for 6 p.m. on 8 May at the parish council building. Thirty minutes before this time there were hundreds of people in front of the building. The women, near the door, sang the chants about Canas' struggle. There was great impatience, and a near certainty that the party's candidates would not show up. Later, a tractor arrived, displaying a large Canas banner and a placard saying 'This [a stick with a hangman's noose] is for those who want to betray Canas'. This vehicle was received with loud applause from the people.

In the garden of the building next to the parish council, where the Republican National Guard (GNR) station operated, an increase in the number of officers and the presence of one senior officer was noted.

At 6.15 p.m., to a murmur of surprise from the people, three vehicles approached, driving up the avenue. Minutes later one of these vehicles was surrounded by people who started to hit and smash it, managing to break the windscreen. The driver, in panic, accelerated through the crowd and left the area. The people were excited. They said to me, 'Did you see that? That's an offence. It's humiliation, their having the cheek to come here'.

One of the occupants of another vehicle, who later turned out to be a police officer in charge of the candidates' safety, went to talk to the GNR commandant, but ended up leaving, threatened by the furious population. Throughout all these events, the GNR never left the stations garden, nor intervened in any way.

This episode reveals several important facts. A population in momentary fusion against an external force, resisting the intrusion of the outside. The PSN candidates, apart from their status as candidates for the parish council, brought with them the asymmetric and oppressive logic of the national political power and crystallized in those brief moments years and years of struggle against the indifference, the superiority and the domination of the outside. The women posted at the door of the council building admitted that their first intention was to strip the female candidate, in an act of humiliation and despoiling, a clear intention to shame. The violence of this intention and the violence of the actual events were justified by the construction of the candidates 
FSES FSES090204-29/6/2004-KREETHI-110686

as representatives of distancing categories, as politicians, as mercenaries, de-personalizing their traits or characteristics. Nothing could weaken this negative categorization, no belonging, no identity.

On the other hand, the inaction of the GNR clearly showed the absolute autarchy of the place, as well as the impotence of the state to claim the monopoly on violence and impose sanctions on the transgressors. I should mention that this episode received practically no media coverage, but was, and still is, a topic of people's conversation. Phrases, actions, gestures and intentions are recalled, and what was or was not possible rediscovered. Even those who admit to being direct actors in the events legitimize their actions with the uncontrollable strength of their emotions, the momentary blindness of reason, attributing the causes of the events to the abstract notion of 'the people'. For example, with phrases like 'The people in fury are uncontrollable', 'Who controls an offended mob?', 'With the mob this is unpredictable', 'With them on the loose, you can't do anything'. The appeal to an abstract entity such as the people or the mob is a culturally acceptable way of contextualizing and legitimizing violence, of activating extremisms without the actors feeling responsible and accountable (Despret 1999). Rather than heroes, what is produced is an entire community united against the outside. Nobody has the right, in this context, to demand protagonism with impunity.

The other episode I will analyze, on the other hand, had huge media coverage, and was the leading story on all the national television stations' afternoon news programmes and made the newspaper headlines. It was to do with the inauguration of the Polis programme, a national urban requalification programme, covering some medium-sized Portuguese cities, by the Prime Minister, António Guterres, in Viseu. A Movement demonstration was planned for that day in the district capital. Although an adviser had managed to arrange a meeting between the Movement's leaders and the Prime Minister, the demonstration was not called off.

In Viseu, after a march through the city's main streets, during which the Movement's chants were sung, the demonstrators gathered in the city centre. They were more than 600 . The leaders had already gone to the Civil Government for the meeting with the Prime Minister. Some minutes later, some of the more radical elements began to pass around the information that the Prime Minister was sitting on the terrace with the MP and district chairman of PS, José Junqueiro. Tempers flared, and comments and jeers were directed at the two. The police cordon managed to hold off the demonstrators' advance.

The official retinue then began the walk which was planned in the programme. Although the majority of the Canas demonstrators were held 
back by the police, about 20 followed the retinue with shouts and jeers. After a frustrated attempt by the Prime Minister to talk with the demonstrators, the walk had to be cut short and the leaders and other important people were collected by buses.

The demonstrators returned to the city centre, where the Movement's leaders told them they had only been met by the Prime Minister's adviser. Tempers once again flared, since these events were seen as another example of the politicians' failure to keep their word, and people were indignant about the indifference of the national authorities. Now a solid group went towards the theatre where the ceremony for the presentation of the programme was taking place. At the end of the narrow street the police had set up a safety cordon. After some confrontations, in which the women and the elderly were much in evidence, the commander of the force allowed the demonstrators to gather in the square in front of the theatre. Chants were sung, and the Movement's leader appealed continually to the Prime Minister to be received, complaining of the failure to keep his promise of a meeting with the Movement. When the authorities left the ceremony, the demonstrators symbolically chanted the slogan 'We are Portuguese, we are Portuguese'.

This episode is one of a long series of actions whose goal is public demonstrations in the presence of national authorities in order to raise the Movement's profile. The goal, in addition to media coverage for the movement, is to publicly embarrass the national political authorities. In this case, the goal was achieved in full, placing - according to the Movement's leaders - the Prime Minister in a difficult situation, where he failed to keep his word in front of the national media.

I should stress the unpredictability of the events and their developments. The action of some of the more radical elements, away from the control and presence of the leaders, brought about a highly effective protest action with a high media profile, allied with the security forces' lack of coordination and inability to act. The later police blockade, confronting women and elderly people, showed the disproportion of the police action at that time. The state did indeed appear repressive.

However, the ludic and festive component of the demonstration must not be forgotten. The pleasure of marching and singing together, and more importantly, the sensation of desacralizing power, seeing fear, reproval and perplexity on the faces of the politicians and government members. These actions and, sometimes, the violence associated with them, are seen as legitimate because they place citizens, who are fighting for a cause they consider just, in confrontation with a distant, arrogant state, which has the power to mobilize large-scale forces of repression. 
FSES FSES090204-29/6/2004-KREETHI-110686

122

REINVENTING DEMOCRACY

But, while the Movement is taken very seriously by its supporters and their personal and emotional involvement is deep, it is also important to mention the ironic tone with which the Movement's actions are analyzed. For example, on the day of the meeting after these events, all the comments concentrated on personal stories of experiencing those events. There was satisfaction and euphoria because of the media coverage of the actions carried out, and regret that these actions had not been more radical. When the man who had fallen during the confrontations with the police and been shown on television arrived, he became the centre of attention for a few brief moments. Many fired playful comments at him, and he, laughing, recounted everything that had happened. This irony relativized the events and allowed the episode to be reintegrated into the community's narrative, and more importantly, produced this very community, the shared closeness between the fallen man and those present. As Allen Feldman (1991: 14) states, 'The event is not what happens. The event is that which can be narrated'.

\section{Personal and Collective Identity Processes}

The collective identity of Canas is based on a past of economic vitality and working-class experience. As the leader of the Movement said in a meeting, 'We are not farmers or peasants. We worked in the factories with more than a thousand workers. We have an industrial, urban mentality. It is not rural, like the surrounding area' (14 March 2000). This workingclass factory experience - materialized in the workers' collective struggles - spread a populist, radical culture, fiercely opposed to the local elites, who were often accused of having supported the integration of Canas into the municipality of Nelas at the time of the liberal struggles in the nineteenth century. As Manuel Alves said:

Canas is a bit feudal. I'm against the attitude of those who are called rich. There are neither rich nor poor. Wealth is more in their inheritance or in the status they inherit. In life they are no more than us. The rich man is the one who works and knows how to work. They are not at all rich. The son of a factory employee gets a university degree and is still Manuel or João. The children of these individuals get a degree and insist on the title 'Doctor'. It still happens. I've never bowed down. I speak as equal to equal. I don't bow down. (24 August 2000)

What the interviewee valorizes is the work ethic against traditional hierarchies. He takes an attitude of resistance and of radical equality and mistrust in relation to the local elites. 
The collective identity also forms part of a long course of struggle and resistance, on a journey of suffering and abandonment, in a framework of injustice (Gamson 1992). This communion of feelings feeds the struggle, and is the support for the most recent arguments for socialization of the younger generations in the reasons that underlie the Movement and its supporters. It is this long story of resistance, suffering and abandonment that unites and mobilizes the inhabitants around the idea of administrative autonomy, seen as the only way to consolidate and develop economically and socially their locality. Disinvestment by the local and national governments is the real indicator that reinforces the narrative of abandonment and what explains the actual strength of the Movement.

Personal identities and personal recognition are intertwined with this collective identity of struggle, resistance and suffering. Each person places herself, assesses herself and is assessed by others in the local hierarchy of credibility and moral conduct. Although birthplace is an important factor in the position in this hierarchy of credibility, some of those who are close to the Movement were not born there, but went to live in the locality when they were children. Two components allow them to legitimize and strengthen their moral position in the town:

(a) the status and behaviour of the family to which they were born; and

(b) personal and family integrity and coherence in their attitudes in favour of the Movement (tradition and biography) and in actions that benefited the town.

In the former, a factor of valorization is status as a worker (as against, for example, the engineers and technicians who came to the companies operating in the town) and the family's integration into the local social networks. In the latter, assessment is made of the individual's abilities to support and be close to the local values and ideals for the restoration of the municipality.

All the people I interviewed claimed as their first personal identification at the spatial level that they were from Canas. Those who were born elsewhere placed their birthplace on equal footing with Canas, or immediately below it in the intensity of identification. ${ }^{26}$ Many also considered themselves to be from the Beira Province, and all said they were Portuguese. The long history of struggle against the local and central governments and the strong and radical localism did not affect the Canas residents' degree of identification with their country. Their discontent was turned against the national and local authorities and politicians, and not against the imagined Portuguese community. 
The struggle for the restoration of the municipality allows an almost daily personal affirmation of values such as integrity, honour, suffering and a capacity for resistance, producing a deeply rooted spirit of community and solidarity. ${ }^{27}$

\section{THE EMANCIPATORY POTENTIAL OF A STRUGGLE}

In an attempt to reflect on the emancipatory potential of the concrete case I am analyzing, I use Santos's proposals when he seeks to establish the principles that can guide the construction of knowledge-emancipation and an emancipatory common sense (1995: Ch.8). Referring especially to the structural spaces of the community and citizenship (1995: 416-41), and paying attention to their specific forms of power (unequal differentiation and domination, respectively), I seek to define the different forms of resistance activated by the participants in the Movement for the Restoration of the Municipality of Canas de Senhorim and the alternative sociabilities they created.

In the communityplace, there is a need to gather the participants in the Movement under a strategy of unity and of concerted actions. This strategic unanimity, associated with severe mistrust of strangers and the outside world, could lead to the production of a fortress community, with strict internal hierarchizations (Santos 1995: 485). However, the practice of weekly meetings, a democratic exercise in power sharing, as well as the rallies for the general public, permit confrontation, debate, assumption of distinct ideas, identities and identifications, and coming together in a common but non-normalizing goal.

The collegial leadership and the weekly meeting with the Movement's participants are organizational innovations that favour the creation of a dialogic public space where people participate. While the existence of the leaders is seen as unavoidable in representing the Movement to the outside world, it is always a provisional leadership, forced by the democratic participation of the people into constant proximity to them and their opinions, problems and perplexities. The egalitarian and fraternal ideology, arising from the working-class history of the town and the vocabulary and repertoire of actions in the revolutionary post-25th of April period, obliges each voice and each opinion to be heard equally.

Simultaneously, the practice of debate and constant analysis of the events most relevant to the Movement and the locality induce a high degree of politicization of all the participants. The great tension derives and here may reside one of the principal obstacles to the creation of an emancipatory common sense - from the need to subordinate the Movement's participants' party-political logics and identifications to 
the interests of the struggle for elevation to the status of municipality. As party identifications are an indelible part of the personal identities of the participants, this situation leads to profound dilemmas of ideology and identity, which can cause lines of fracture, silencing or even censure in the community. Furthermore, the popular base of the Movement excludes the majority of the representatives of the locality's economic and cultural elites. This assumed populism, associated with a negative and critical view of the logic of traditional domination, also establishes dynamic tensions within the locality and its connection to external powers and spaces.

The participation of women in the community's public space and in the wider political space takes on special importance in the analysis of this Movement. This visibility derives from women's decisive role in the events that left their mark on the locality in 1982, leading to the foundation of the Movement. Since then, their presence has been unquestionable and is completely legitimized. The major obstacle to a full emancipatory practice lies in the almost total absence of women from the Movement's leadership, reproducing the patriarchal logic dominant in the household place. And, as Boaventura de Sousa Santos says (1995: 441), struggles for emancipation have to pay attention to all the structural places, and not confine themselves to those where counterhegemonic practices are most visible. The interviews I conducted and my conversations with women of the movement show a clear awareness of this situation, and although they justify delegating the powers of representation to the men, it is hoped that in the future there will be greater pressure for the women to play a larger and more important part in the Movement's leadership structures.

It is in the structural place of citizenship that the Movement marks its position most clearly. Indeed, the strategy in recent years has been to confront the state and its national representatives, projecting the struggle into the national ambit. Claiming a participatory and radical democracy, the Movement's leaders and participants opted for rebel actions, trying, as Boaventura de Sousa Santos says, 'to redistribute the anxiety and insecurity socially, creating conditions for the anxiety of the excluded to be transformed into a cause of anxiety for the included' (1998: 32). In addition to creating space-times which promote democratic deliberations, as we saw earlier, they brought about a desacralization of the national and local representatives of the state. This real and symbolic distancing of the Movement's participants from the representatives of the national political system did not induce a distancing of the identity markers of an imagined Portuguese community. Criticism of the political system in force does not go further to a criticism of a democratic regime. 
FSES FSES090204-29/6/2004-KREETHI-110686

126

REINVENTING DEMOCRACY

The favoured target of the criticisms of the Movement's participants is the inability of the state to draw up alternative institutional designs (Santos 1998: 47). The administrative division of Portugal has remained almost unaltered since 25 April 1974, and there are no institutional structures to allow effective inspection of discriminatory practices on the part of the municipal authorities. According to the arguments of the Movement's sympathizers, the alternative would include revision of the geo-demographic criteria for the creation of municipalities and greater attribution of autonomy and responsibilities to local governments at the parish level.

The most radical act of the Movement's participants and sympathizers was the destruction of their voting cards and the systematic boycott of all elections in the locality. These actions represented an extreme affirmation of their rights of political citizenship, forcing the national and municipal powers into continued attention to the locality's political process. It is a clear refusal and a denunciation of the total failure of representative democracy and of the current political system. This refusal of the formal rights of political citizenship placed the locality at the centre of the national political and media debate.

In this essay I have given special emphasis to the subjective and collective identification processes of the Movement's participants. To assess the production of emancipatory, individual and collective subjectivities, I turn to the topoi defined by Santos: the frontier, the baroque and the South (1995: 489-518). That is because, as the author states, these topoi 'preside over the reinvention of a subjectivity capable of and willing to explore the emancipatory potentialities of paradigmatic transition' (1995: 517).

The metaphors of the frontier and the south should be read, in the case of the Movement, as the affirmation of interiority, of a peripheral space in the country's interior, which allows a critical deconstruction of the hegemonic logic of a centralizing state. From the metaphor of the frontier, the important things seem to be retention of the selective and instrumental use of traditions, the invention of new forms of sociability and the production of weak hierarchies (Santos 1995: 491-3). An example of the first is the invocation of the fact that Canas had been a municipality for more than 700 years, giving historical legitimacy and solidity to the current demands. Furthermore, the locality's tradition of labour feeds the rhetoric of brotherhood and solidarity and the unifying dynamics of an ideological familism. ${ }^{28}$ Traditions feed the town's political utopia.

As for the new forms of sociability and weak hegemonies, the weekly meetings, the rallies and the annual commemoration of the events of 1982 
produce and reproduce a public space of proximity, of solidarity and, above all, a non-commercial communion between equal citizens.

From the metaphor that permits the development of a baroque subjectivity (Santos 1995: 499-506), I stress the predominantly local space linked to the movement. This radical localism mobilizes the Movement's participants politically and socially, and keeps the citizens informed about political and party life at the national level. As I described earlier, the Movement's activities, from the most banal to the most expressive, are marked by constant moments of ludic distance, of irony and laughter, and even by a logic of subversion. The refusal of the locality's minor position and the extreme egalitarianism are shown in constant expressions of non-conformism, of revolt and of counterhegemonic logics and actions.

From the subjectivity of the South, the most relevant aspect in this context is the personal and collective memories which, in everyday conversations and some of the Movement's actions (hunger strikes), emphasize the idea of suffering, of a loss of decent and dignified living conditions in the community. This phenomenology of suffering (Santos 1995: 516) creates ties of solidarity and allows the construction of analogies with situations of exploitation and oppression which go from the national space to the world space. Several times I heard the case of Canas compared to the situation in East Timor or the Basque Country by the Movement's participants. If these comparisons may seem exaggerated to many commentators and journalists, they forget the thread which wove and connected them, the suffering, the refusal to accept lack of recognition and the ongoing search for greater dignity of the Movement's participants as people and citizens.

\section{CONCLUSION}

The stories and narratives recounted, the collective memory of struggle, crystallized into some important moments, besides being concrete indicators of the capacity for struggle and protest, represent a possibility for emancipatory practices that challenge the hegemony of the state.

The narrathemes of the Canas residents who support its Movement and its concrete actions of protest, seek to re-specify and deconstruct, on a basis of populism and radical egalitarianism, the concepts of freedom, democracy and power. In the intertwining of personal and collective memories, the dream is the affirmation of their autonomy and the practice is one of resistance and affirmation towards the outside, in the search for personal and collective recognition. These practices have produced alternative sociabilities in regard to women's participation in the public 
FSES FSES090204-29/6/2004-KREETHI-110686

space and have given equal access to the possibility of all participants having their voices heard.

The greatest obstacles to the constitution of an emancipatory common sense are the reproduction of the patriarchal domination in the representation work of the Movement, that is, the non-access of women to leadership posts, and the populism which leads to the exclusion of the elites, creating internal tensions in the community and in its relationship with outside powers.

\section{NOTES}

1. This work is based on field observation, from Feb. to Dec. 2000, of the weekly meetings of this Movement with the population, on participation in the Movement's rallies and demonstrations, and on interviews with its leaders and supporters. For documental analysis I use documents produced by the movement, a systematic analysis of the JN from 1974 to 2000 and news from other daily and weekly newspapers, in addition to the minutes of the meetings of the Canas de Senhorim parish council, from 1977 to 1998.

2. The exceptions being the creation of the municipality of Amadora one year after the revolution of 1974 and the municipalities of Odivelas, Trofa and Vizela in 1998. The Law on the Creation of Municipalities (Law no 142/85, of 18 November 1985) was approved by the Parliament in order to restrain the creation of new municipalities. This law established that only localities with a territory of 10 squared kilometers and more than 10,000 registered voters could apply to the status of municipality. These criteria excluded, in a small country like Portugal, almost every locality from the rural and the interior from the possibility of becoming a municipality.

3. It is important to note that until recently Canas de Senhorim was a highly industrialized parish. In 1924 the Calcium Carbide Factory began to operate, later becoming the Portuguese Electric Oven Company. This company would close in 1987. It came to have nearly a thousand workers. The mines of Urgeiriça are also located in this parish, operated today by the National Uranium Company, and are currently being deactivated. They came to employ a large number of workers, but now have only 50 . It is forecast that in the near future there will be only two or three jobs left.

4. Men's unemployment rate is very low in the town, and although women's unemployment rate is higher it is below the district and national averages.

5. On the second mandate (1979-82) he was elected for AD (Democratic Alliance), a coalition government by PPD and CDS.

6. Later this party would change its name to PSD. The coalition was in power since 1980.

7. From here on I shall use the abbreviation JN for Jornal de Notícias.

8. All names are pseudonyms, with the exception of the Movement's leader, who because of his visibility, and by his own choice, agreed I should use his real name. Although some interviewees agreed to the use of their real name, I opted to use pseudonyms.

9. He has been reelected as Mayor of Nelas, for the PS, in the 1993, 1997 and 2001 local elections.

10. When CDS submitted the bill for the creation of the municipality of Canas in 1982, PS, PCP, and MDP (Portuguese Democratic Movement) - all opposition parties - showed themselves in favour. From 1995 to 2002, with PS in power, PSD, CDS/PP, PCP and BE (Left Bloc) showed themselves in favour of raising Canas to the status of municipality. And from 2002 on, with a coalition government by PSD and CDS/PP, only PS is against the raising of Canas to municipality. 
FSES FSES090204-29/6/2004-KREETHI-110686

\section{MEMORY, POPULISM AND DEMOCRACY}

11. A typical meeting will have around 30 people, the number varying according to the season and whether or not there are burning issues or imminent broader actions.

12. From the beginning of 1999 to 2002, owing to the parish council's resignation, the running of the Canas de Senhorim parish has been in the hands of an administrative committee (chairman and secretaries who were in office; the chairman is from PS, one secretary is from PSD and the other is from CDS/PP). Since then, elections to constitute a new council have been systematically boycotted by the population, and the Movement became the only accepted political force in town. The national political parties representatives in the town agreed not to interfere with the Movement's political actions. In 2002, now with a new national government, there were local elections in Canas and the only candidates were from the Movement. Since then the parish council and assembly have been run by the Movement.

13. According to McAdam and Jayyusi (1991), all social movements are faced with the need to choose between three strategic options: institutionalized or non-institutionalized action; legal or non-legal actions; violent or non-violent actions. This favourable national alignment of political forces has, unexpectedly, become true in the general elections of 2002, after the resignation of former Prime-Minister António Guterres of the PS.

14. It was reported that, in Vizela, a town that also fought to become a municipality and managed to get this status in 1998, people who were against its elevation to the status of municipality were thrown out, although they had been born there.

15. Familism is a factor of union between people and of political mobilization. It is different from the so-called amoral familism proposed by Edward Banfield. For an application of the latter concept to the political processes and dynamics in Portugal, see Cabral (1999).

16. This democratic exercise can be defined as populist, not in the negative and pejorative sense given by many political and social scientists, but in the sense given by William Gamson (1992: 89-90) in his study about injustice frames used by interviewees of the working classes. For Gamson, populism includes a set of class images that oppose common citizens, simple people, to the powerful and rich, to the capitalist classes. Enrique Dussel also proposes the use of the concept of 'the people' that subsumes the concept of social class and allows us to transcend the dogmatism of class analysis (Gomez 2001: 36).

17. In a conversation I had with one of the more radical elements, he compared the situation of Canas with that of the Basque country, saying explicitly that what was needed was a practice similar to that of ETA. But, according to him, this would have to be done away from the structures of the Movement and of the older people, who maintain a logic of institutional political struggle, still connected with the ideas of negotiation.

18. Bill 478/VII, submitted on 28 February 1998. In this legislature (1995-99), PCP also submitted a bill for raising Canas to municipal status. In the following legislature (1999-2002), PSD again submitted a bill to the same end. CDS/PP and the BE have also submitted projects for raising Canas to the status of municipality. In the 2002-06 legislature PSD has submitted a bill, and the BE and PCP have taken similar initiatives.

19. The submission of bills by PCP distanced many sympathizers who were politically more to the right from the Movement's leadership, according to one interviewee.

20. Petition signed by more than four thousand citizens of Canas de Senhorim. The letter addressed to the Speaker that accompanied the petition mentioned the approval of new municipalities (Vizela, Trofa and Odivelas), as well as the fact that Canas had been forgotten. The letter questioned whether there were first-class and second-class Portuguese citizens.

21. In the Diário de Notícias, the cartoonist Bandeira published the following dialogue between a tourist and a character on 11 March: 'Character: Parliament? Let me see..., go down this street and turn left, then turn right. When you see "Canas de Senhorim in Struggle”, it's next door'. In Público, on 10 March, Luís Afonso's cartoon had the following dialogue: 'Bar customer: Inhabitants of Canas de Senhorim say the situation 
FSES FSES090204-29/6/2004-KREETHI-110686

in the municipality of Nelas is like that of the Timorese in Indonesia. Barman: Damn. Another headache for the UN'.

22. A long article by journalist Pereira in the Expresso(1 May 1999) was entitled 'Canas de Senhorim without a shadow of sin'. Here several members of the Movement were interviewed, including the leader, and it was stated that they faced the condemnation of public opinion. At the institutional and legal level, the Attorney General filed a suit against the people of Canas de Senhorim for insulting the President. This lawsuit was eventually withdrawn at the request of the President himself (JN, 22 May 1999).

23. The opinion article by Valada in the JN (2 May 1999) concluded differently 'The noisy demonstration by the people of Canas de Senhorim, beyond the scandal it may represent in terms of protocol, represents in itself only an act of civil liberty. Would it have been possible without the 25th of April? Would it have been possible without the calm of President Jorge Sampaio? Those who censure do not understand'. An interesting reading of the situation in Canas was put forward almost a year later, by Miguel Portas, leader of the BE, a party which also submitted a bill for raising Canas to municipality status. Reporting the rally he had held in Canas with Luís Fazenda, another BE leader, he said in his weekly column that 'The air we were breathing was that of a 25th of April announced, but not yet concretized ... For example, I do not believe it is possible to force people to be governed against their will and in conflict with their neighbour. When the majority of the population wants a separation, the Republic should help. Or the conflict of the people will come to be with the Republic itself' (Diário de Notícias, 11 May 2000).

24. One of the interviewees told me that the date was chosen strategically, because, due to the symbolism of the date and the great press coverage, they knew it would be almost impossible for there to be any police repression.

25 . This is a small right wing party with no parliamentary representation.

26. The identities claimed depend on the context and the purpose of the narratives and stories they tell. As Harvey Sacks (Jayyusi 1991: 237) pointed out, in his writings on categorization membership mechanisms, one must distinguish, as regards identities, between the correct descriptions (man, husband, father, worker, trade-unionist, resident of Canas, resident of the Beira, Portuguese, and so on.) and those that are appropriate for the concrete context of action (worker, resident of Canas, amd so on.).

27. Recently, on 12 June 2003, the Portuguese Parliament has approved an amendment to Law no. 142/85, of 18 November 1985. The approved amendment allows now the granting of the status of municipality to parishes that have strong historical traditions or exceptional features. Following this amendment, the Portuguese Parliament has approved a bill, on 1 July 2003, that allows Canas de Senhorim to regain its status of municipality. The status of municipality was also granted to the parish of Fátima, because of its international role as a Catholic sanctuary. Both the amendment proposal and the bill are waiting for the final decision of the President of the Republic. The amendment and the bill were made possible because, after the general elections of 2002, there is now in Portugal a coalition government of the PSD and the CDS/PP.

28. In the case of some regions of Colombia, a rather different context, Sanin and Jaramillo (2003) argue that the emancipatory potential is in the idea of the person and in the individualism which endows the subjects with differences and potentials. These concepts of the human person and of individualism may go against the microterritorialized collective dynamics which, in the regions studied by the authors, give rise to levelling and uniformising territorial identities which inhibit the political and civic participation of the members of the different groups and movements. The action of the state is also marked by great ambiguity. 
FSES FSES090204-29/6/2004-KREETHI-110686

MEMORY, POPULISM AND DEMOCRACY

\section{REFERENCES}

Alvarez, S., et al. (1998): 'Introduction: The Cultural and the Political in Latin American Social Movements', in Sonia Alvarez (eds), Cultures of Politics Politics of Cultures. Re-Visioning Latin American Social Movements, Boulder: Westview Press, pp.1-29.

Augé, M. (1998): Les formes de l'oubli, Paris: Editions Payot et Rivages.

Boltanski, L. and È. Chiapello (1999): Le nouvel esprit du capitalisme, Paris: Gallimard.

Cabral, M.V. (1999): "Autoritarismo de estado, "distância ao poder" e "familismo amoral" - uma pesquisa em progresso', Brasil-Portugal Congress Year 2000, Sociology and Anthropology Section. Recife: Sept.-Oct.

Despret, V. (1999): Ces émotions que nous fabriquent. Ethnopsychologie de l'autenticité, Le Plessis-Robinson: Institut Synthélabo.

Feldman, A. (1991): Formations of Violence. The Narrative of Body and Political Terror in Northern Ireland, Chicago: University of Chicago Press.

Gamson, W. (1992): Talking Politics, Cambridge: Cambridge University Press.

Gomez, F. (2001): 'Ethics Is the Original Philosophy; or, The Barbarian Words Coming from the Third World: An Interview with Enrique Dussel', Boundary 2, 28/1, pp.19-73.

Heinich, N. (1999): L'épreuve de la grandeur. Prix littéraires et reconaissance, Paris: La Découverte.

Jayyusi, L. (1991): 'Values and Moral Judgement: Communicative Praxis as a Moral Order', in Graham Button (ed.), Ethnomethodology and the Human Sciences, New York: Cambridge University Press, pp.227-51.

Jasper, J. (1996): The Art of Moral Prostest. Culture, Biography, and Creativity in Social Movements, Chicago: The University of Chicago Press.

McAdam, D. and S.Tarrow (2000): 'Nonviolence as Contentious Interaction', PS June, pp.149-54.

Movimento de Restauração do Concelho de Canas de Senhorim (1999): Processo Relativo à Restauração do Concelho de Canas de Senhorim. Canas de Senhorim.

Mouraz, A. (ed.) (1996): Canas de Senhorim. História e Património, Canas de Senhorim: Junta de Freguesia.

Ruas, H.B. (1994): 'O poder local', António Reis (org.), Portugal 20 anos de democracia, Circulo de Leitores: Lisboa, pp.90-103.

Rubin, J. (1998): 'Contradiction and Ambiguity in a Radical Popular Movement', in Sonia Alvarez et al. (eds.), Cultures of Politics Politics of Cultures. Re-Visioning Latin American Social Movements, Boulder: Westview Press, pp.141-64.

Ruivo, F. (2000): O Estado labiríntico: o poder relacional entre poderes local e central em Portugal, Oporto: Edições Afrontamento.

Ruivo, F. and D. Francisco (1999): 'O Poder Local entre centro e periferias', Revista Critica de Ciências Sociais, February, pp.281-306.

Sanín, F.G. and A.M. Jaramillo (2003): 'Pactos paradoxais', in Boaventura de Sousa Santos (ed.), Reconhecer para libertar. Os caminhos do cosmopolitismo multicultural, Rio de Janeiro: Civilização Brasileira, pp.249-87.

Santos, B. de S. (ed.) (2003): Reconhecer para libertar. Os caminhos do cosmopolitismo multicultural, Rio de Janeiro: Civilização Brasileira.

Santos, B. de S. (1995): Toward a New Common Sense. Law, Science and Politics in the Paradigmatic Transition, New York: Routledge.

Various (1975): Canas de Senhorim. O que somos o que queremos, Canas de Senhorim: Comissão de Moradores. 


\section{Author Query Sheet}

\begin{tabular}{|l|l|}
\hline \multicolumn{2}{|c|}{ Manuscript Information } \\
\hline $\begin{array}{l}\text { Journal } \\
\text { Acronym }\end{array}$ & fSES \\
\hline $\begin{array}{l}\text { Volume and } \\
\text { issue }\end{array}$ & 9.2 \\
\hline Author name & Mendes \\
\hline $\begin{array}{l}\text { Manuscript } \\
\text { No. (if } \\
\text { applicable) }\end{array}$ & 04 \\
\hline
\end{tabular}

AUTHOR: The following queries have arisen during the editing of your manuscript. Please answer the queries by marking necessary corrections at the appropriate positions on the PROOFS. Do not answer the queries on the query sheet itself. Please also return a copy of the query sheet with your corrected proofs. 
1. $\quad$ It was the first violent action in the municipality's reivindicative [?? Is this word correct as printed?] process, showing the local will to resist the impositions of the municipal, district and national authorities. 